Egyptian Journal of Aquatic Biology \& Fisheries

Zoology Department, Faculty of Science,

Ain Shams University, Cairo, Egypt.

ISSN $1110-6131$

Vol. 25(5): 131 - 145 (2021)

www.ejabf.journals.ekb.eg

\title{
The Seasonal Fluctuations of Phytoplankton Diversity and its Biochemical Components in Lake Qarun, Egypt
}

\author{
Nasser S. Flefil* and Abeer M. A. Mahmoud \\ National Institute of Oceanography and Fisheries, Egypt \\ *Corresponding Author: naserflefil@yahoo.com
}

\section{ARTICLE INFO \\ Article History: \\ Received: June 1, 2021 \\ Accepted: Aug. 27, 2021 \\ Online: Sept. 18, 2021}

Keywords:

Lake Qarun,

Drains,

Phytoplankton,

Seasons,

PCA,

Biochemical

components.

\section{ABSTRACT}

A one- year seasonal study was carried out to estimate the algal population and its biochemical contents in Lake Qarun in Egypt. Twelve samples representing Lake Qarun and two drains (El-Bats and El-Wadi) were examined. Bacillariophyta was the most dominant in phytoplankton assemblages. The highest seasonal phytoplankton density was recorded during summer, whereas the lowest was in autumn. The lowest spatial phytoplankton density, chlorophyll (a), and carotenoid concentrations were recorded in drains. ANOVA revealed significant differences between seasons and stations in the density of phytoplankton species, protein, carbohydrate, and lipid. Principal component analysis (PCA) results showed that water temperature was positively correlated with Ochrophyta, Cyanobacteria, Cryptophyta and some dominant phytoplankton species, meanwhile; water temperature was negatively correlated with Bacillariophyta, some dominant phytoplankton species, Chl (a), carotenoid, protein, carbohydrate, and lipid. Hence, water temperature and nutrients $\left(\mathrm{NO}_{3}\right.$ and $\left.\mathrm{PO}_{4}\right)$, drained into the lake, play a major role in the trophic state changes of Lake Qarun, and its effect on the phytoplankton community and other environmental conditions was detected during the seasons of the year.

\section{INTRODUCTION}

Based on historic and scientific importance, Lake Qarun is considered a unique ecosystem. It is a natural reservoir in Fayoum depression, receiving its water from two main drains; namely, El-Bats drain (at the north-eastern corner) and El-Wadi drain (at the midpoint of the southern shore). Hussein et al. (2008) reported that Lake Qarun suffers from severe pollution problems due to different domestic and industrial waste drainage, even though it was classified as a protected area back in 1989.

Several studies were carried out to investigate seasonal and temporal effects on phytoplankton community and assemblage in Lake Qarun, and the prevalent finding was that phytoplankton was normally flourished in spring and summer, while lower algae density was observed in autumn and winter (Abdel-Monem \& Kanswa, 2001; Fathi \& Flower, 2005; Hussian et al., 2019). Physiological and nutritional condition of 
phytoplankton is indicated by its biochemical composition. An equalize biochemical pattern indicates a healthful and productive metabolism in the autotrophic levels, which can aid the good performance of higher-level organisms. The amount of biochemical measurements from different aquatic ecosystems around the world has increased. Lately, as a response to climate changes, biochemical patterns have been used as a tool to follow the changes in the physiological status of phytoplankton (Bhavya et al., 2019).

Photosynthetic primary production generates different important biochemical components such as proteins, carbohydrates, and lipids within the phytoplankton biomass. These biochemical constitutes are essential indicators of algal species' physiological state and nutritional value (Lee et al., 2009; Mahmoud, 2016).

Among the biochemical components, proteins play a significant role in enzymatic catalysis and performance of the phytoplankton communities (Lindqvist \& Lignell, 1997).

Lipid and carbohydrate are essential components for all cell membranes and they perform as greater energy reservoirs in phytoplankton bodies (Parrish, 1987).Thus, under a nitrogen starving environment, protein performance is suppressed; while instead, lipid and carbohydrate production is enhanced (Yun et al., 2015). Protein production is majorly dependent on the nitrogen substrates available at the time of photosynthesis, and hence, low protein contents generally occur due to poor nitrogenous nutrient conditions (Danovaro et al., 2000). In contrast, lipid and carbohydrate are non-nitrogenous constitutes, and their concentrations are independent on nitrogenous nutrient availability (Takagi et al., 2000). The seasonal and regional variation leads to changes in the biochemical composition of phytoplankton communities, affecting the nutritional quality of the aquatic system (Boëchat \& Giani, 2008).

The aim of this study is to assess the quantitative and qualitative estimations of phytoplankton community at Lake Qarun, in relation to the biological and environmental conditions.

\section{MATERIALS AND METHODS}

\section{The study area and sampling}

The Lake Qarun is Egypt's third-largest lake. It is located 90 kilometers southwest of Cairo in the province of Fayoum. The lake is now used as a general reservoir for both sewage and agricultural wastewater treatment. Excess agricultural water flows through two main drains, El-Wadi and El-Bats, to the Lake Qarun. It became a saline lake in the early 1900s due to freshwater flow reduction besides the high evaporation rate (ElShabrawy \& Dumont, 2009).

Ten sampling stations were seasonally selected to represent different parts of Lake Qarun in addition to El-Bats and El-Wadi Drains from Autumn 2018 to Summer 2019 (Table 1 \& Fig. 1). 
Table 1. Description of sampling stations from Lake Qarun

\begin{tabular}{|c|l|c|c|c|}
\hline Station & \multicolumn{1}{|c|}{ Feature of station } & $\begin{array}{c}\text { Average } \\
\text { of } \quad \text { Depth }\end{array}$ & Longitude & Latitude \\
\hline $\mathbf{1}$ & Opposite to El-Bats Drain & 2.00 & $30^{\circ} 48^{\prime} 47.2^{\prime \prime}$ & $29^{\circ} 31^{\prime} 04.1^{\prime \prime}$ \\
\hline $\mathbf{2}$ & Opposite to The Auberge & 3.00 & $30^{\circ} 47^{\prime} 23.1^{\prime \prime}$ & $29^{\circ} 28^{\prime} 58.1^{\prime \prime}$ \\
\hline $\mathbf{3}$ & Far North-East of Lake & 4.00 & $30^{\circ} 44^{\prime} 58.1^{\prime \prime}$ & $29^{\circ} 30^{\prime} 56.5^{\prime \prime}$ \\
\hline $\mathbf{4}$ & Opposite to Abou Nema lasn & 5.00 & $30^{\circ} 42^{\prime} 53.9^{\prime \prime}$ & $29^{\circ} 29^{\prime} 11.4^{\prime \prime}$ \\
\hline $\mathbf{5}$ & Hkor Maeiouf (Middle lake) & 5.00 & $30^{\circ} 40^{\prime} 57.4^{\prime \prime}$ & $29^{\circ} 29^{\prime} 37.4^{\prime \prime}$ \\
\hline $\mathbf{6}$ & North of El-Karn Island (Middle lake) & 7.50 & $30^{\circ} 37^{\prime} 10.9^{\prime \prime}$ & $29^{\circ} 29^{\prime} 36.8^{\prime \prime}$ \\
\hline $\mathbf{7}$ & Opposite to El-Wadi Drain & 2.50 & $30^{\circ} 37^{\prime} 43.4^{\prime \prime}$ & $29^{\circ} 26^{\prime} 49.4^{\prime \prime}$ \\
\hline $\mathbf{8}$ & Opposite to Maser for reconstruction & 5.50 & $30^{\circ} 34^{\prime} 51.3^{\prime \prime}$ & $29^{\circ} 27^{\prime} 41.0^{\prime \prime}$ \\
\hline $\mathbf{9}$ & West Lake & 4.00 & $30^{\circ} 31^{\prime} 09.6^{\prime \prime}$ & $29^{\circ} 25^{\prime} 42.4^{\prime \prime}$ \\
\hline $\mathbf{1 0}$ & Malahet Mizar (Far West of Lake) & 4.00 & $30^{\circ} 26^{\prime} 08.4^{\prime \prime}$ & $29^{\circ} 26^{\prime} 37.1^{\prime \prime}$ \\
\hline $\mathbf{1 1}$ & El-Bats Drain & 1.50 & $30^{\circ} 49^{\prime} 20.8^{\prime \prime}$ & $29^{\circ} 32^{\prime} 52.4^{\prime \prime}$ \\
\hline $\mathbf{1 2}$ & El-Wadi Drain & 1.50 & $30^{\circ} 38^{\prime} 08.4^{\prime \prime}$ & $29^{\circ} 30^{\prime} 23.5^{\prime \prime}$ \\
\hline
\end{tabular}

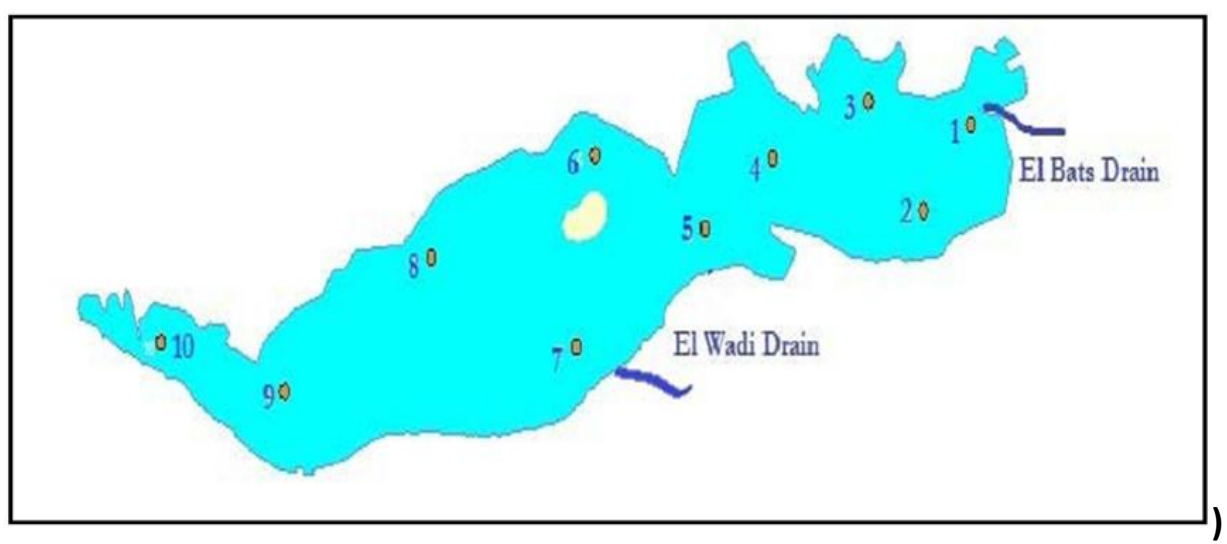

Fig. 1. Map of samples collection sites in Lake Qarun (GAFRD, 2012)

\section{Chlorophyll (a) and carotenoid}

Water samples were collected from each station in plastic bottles, and then, $25 \mathrm{ml}$ was filtered using Whatman GF/F fiber circles for biochemical analysis.

In the laboratory, filter paper prepared in the field containing phytoplankton filtrate was socked in $5 \mathrm{ml}$ acetone (90\%) for extracting chlorophylls and carotenoid and preserved under dark and cold conditions overnight. The samples were then shaken well and centrifuged. The clear extract was siphoned carefully and measured spectrophotometrically at 750,664, 647,630, and 480nm with $90 \%$ acetone as a blank to measure Chlorophyll (a) and carotenoid, using Kontron 930 UV visible spectrophotometer. The concentrations were calculated according to the trichromatic equation reported in APHA (2017). 


\section{Biochemical analysis}

Total protein was determined by the Biuret method (David \& Hazel, 1998). The hydrolysis of carbohydrate was carried out using Myklestad and Haug's method (1972) and determined by the method of Dubois et al. (1956). The total lipid was determined according to the method of Chabrol and Castellano (1961).

\section{Phytoplankton investigation}

In the laboratory, water samples were prepared for phytoplankton examination. 500 $\mathrm{ml}$ of the preserved water samples, with $4 \%$ neutral formalin and Lugol's iodine solution, was transferred in a glass cylinder. Extra Lugol's iodine solution was added until the color turned to faint tea color, covered with aluminum foil, and allowed for five days to settle phytoplankton cells (APHA, 2017). A 90\% of the supernatant fluid was siphoned off, and the sample volume was adjusted to a fixed volume $(50 \mathrm{ml})$ that was transferred to a small plastic vial for microscopic examination. Drop method was applied for counting and identifying the phytoplankton secies (APHA, 2017), and triplicate samples (2 or $5 \mu 1$ ) were taken and examined under inverted microscope ZEISS IM 4738; with magnification power of 40 and 100x. The results of phytoplankton density were presented as a number of units per litre (units/l). The data used in phytoplankton identification and classification were those of Desikachary (1959), Starmach (1974), Httl-Hand (1988), Popovsky and Pfiester (1990), Krammer and Lange- Bertalot (1991), Ward and Whipple (1992), Verlencar and Desai (2004), Lee (2008), Bellinger and Sigee (2010, 2015) and_Munshi et al. (2010). The currently accepted nomenclature of all taxa has been given according to Guiry and Guiry (2021).

\section{Statistical analysis}

Pearson's correlation was performed to assess the relationship between the phytoplankton and its biochemical components with the surrounding physicochemical parameter. These relations were also examined with a normalized principal component analysis (PCA). The data recorded in this study were examined with PCA using XLSTAT software version (Addinsoft, 2010). Origin 19.0 software was also used for the creation of some figures.

\section{RESULTS AND DISCUSSION}

\section{Phytoplankton community structure}

A number of 93 species were recorded in Lake Qarun; along the investigated period, phytoplankton was determined to belong to 8 major phyla: Bacillariophyta (37 spp.); Chlorophyta (19 spp.); Cyanobacteria (17 spp.); Miozoa (Dinoflagellates) (8 spp.); Euglenozoa (4 spp.); Ochrophyta (3 spp.); Charophyta (3 spp.); and Cryptophyta (2 spp.).

The annual average of the phylum composition ratio cleared that Bacillariophyta was the most predominated, forming about $35.4 \%$ of the total phytoplankton density, followed by Cyanobacteria, representing about $26.8 \%$, while Miozoa became in the third position, constituting about 20.5\%. Chlorophyta, Charophyta, Euglenophyta, Ochrophyta, and 
Cryptophyta were presented with a low ratio $(8,5.4,2.3,1.4$, and $0.2 \%$, respectively) (Fig. 2). A similar finding was recorded by Abdel-Monem (2001), Hussian et al. (2014, 2019) and Napiórkowska-Krzebietke et al. (2016).

Seasonal variation in phytoplankton densities cleared the best phytoplankton counting during summer, with a maximum average of $18930 \times 10^{4}$ unit/l; forming about $32.9 \%$ from the annual average of the standing crop. In comparison, the least phytoplankton counting was recorded through autumn that amounted to $10475 \times 10^{4}$ unit/l, constituting about $18.2 \%$ of the annual average of the standing crop. The highest annual phytoplankton density was recorded in site (3) (North east of the lake), while the lowest was recorded in drains. An approximate result was observed by Abdel-Monem and Kanswa (2001), Fathi and Flower (2005), and Sharma and Tiwari (2018).

The annual average of the population densities in the selected stations revealed that the best population was detected in site (3) (North east of lake) and the least population in El-Wadi drain. The seasonal and spatial distributions of phytoplankton in Lake Qarun and the associated drains, through the studying period, are shown in Tables ( $2 \& 3)$.

These results are confirmed by Pearson correlation matrix and principal component analysis (PCA) (Figs. 6 \& 7) which showed that, a water temperature was positively correlatedwith Ochrophyta, Cyanobacteria, Cryptophyta $(\mathrm{r}=0.54,0.48,0.32, \mathrm{P}<0.05)$ and some dominant phytoplankton species (Actinocyclus octonarius var. ralfsii; Aphanocapsa elachista; Leptolyngbya laminosa; Leptolyngbya tenuis; Ochromonas sp.; Schroederia nitzschioides; Thalassiosira lacustris). Meanwhile, water temperature was negatively correlatedwith Bacillariophyta, $(\mathrm{r}=-0.48, \mathrm{P}<0.05)$ and some dominant phytoplankton species (Kirchneriella lunaris; Monoraphidium contortum; Nitzschia acicularis; Pantocsekiella ocellata).

Table 2. Seasonal variations in phytoplankton densities (No. of units $\left.\times 10^{4} / \mathrm{l}\right)$ in Lake Qarun during 2018-2019

\begin{tabular}{cccccc}
\hline Site & \multicolumn{5}{c}{ Season } \\
\cline { 2 - 5 } & Autumn & Winter & Spring & Summer & Annual average \\
\hline $\mathbf{1}$ & 985 & 755 & 860 & 700 & 825 \\
$\mathbf{2}$ & 1480 & 2715 & 395 & 2665 & 1813.75 \\
$\mathbf{3}$ & 815 & 4795 & 830 & 2115 & 2138.75 \\
$\mathbf{4}$ & 965 & 1405 & 745 & 935 & 1012.5 \\
$\mathbf{5}$ & 785 & 770 & 1960 & 2515 & 1507.5 \\
$\mathbf{6}$ & 2075 & 580 & 755 & 1480 & 1222.5 \\
$\mathbf{7}$ & 345 & 800 & 955 & 1315 & 853.75 \\
$\mathbf{8}$ & 255 & 1235 & 670 & 800 & 740 \\
$\mathbf{9}$ & 325 & 1270 & 1725 & 2245 & 1391.25 \\
$\mathbf{1 0}$ & 1305 & 2595 & 830 & 3235 & 1991.25 \\
El-Bats Drain & 830 & 295 & 765 & 555 & 611.25 \\
El-Wadi Drain & 310 & 160 & 305 & 370 & 286.25 \\
\hline Seasonal average & 872.92 & 1447.92 & 899.58 & 1577.50 & - \\
\hline
\end{tabular}


Table 3. Seasonal variation of phytoplankton phyla density (No. of units $\left.\times 10^{4} / 1\right)$ in Lake Qarun during 2018-2019

\begin{tabular}{cccccc}
\hline Algal phylum & \multicolumn{5}{c}{ Season } \\
\cline { 2 - 6 } & Autumn & Winter & Spring & Summer & Annual average \\
\hline Bacillariophyta & 4050 & 9670 & 3895 & 2750 & 5091.25 \\
Cyanobacteria & 2115 & 1360 & 2315 & 9655 & 3861.25 \\
Dinophyta & 2660 & 3445 & 2165 & 3515 & 2946.25 \\
Chlorophyta & 530 & 2135 & 455 & 1480 & 1150 \\
Charophyta & 245 & 690 & 1655 & 545 & 783.75 \\
Euglenophyta & 855 & 75 & 280 & 115 & 331.25 \\
Ochrophyta & 20 & 0 & 30 & 760 & 202.5 \\
Cryptophyta & 0 & 0 & 0 & 110 & 27.5 \\
\hline Total count & 10475 & 17375 & 10795 & 18930 & - \\
\hline
\end{tabular}

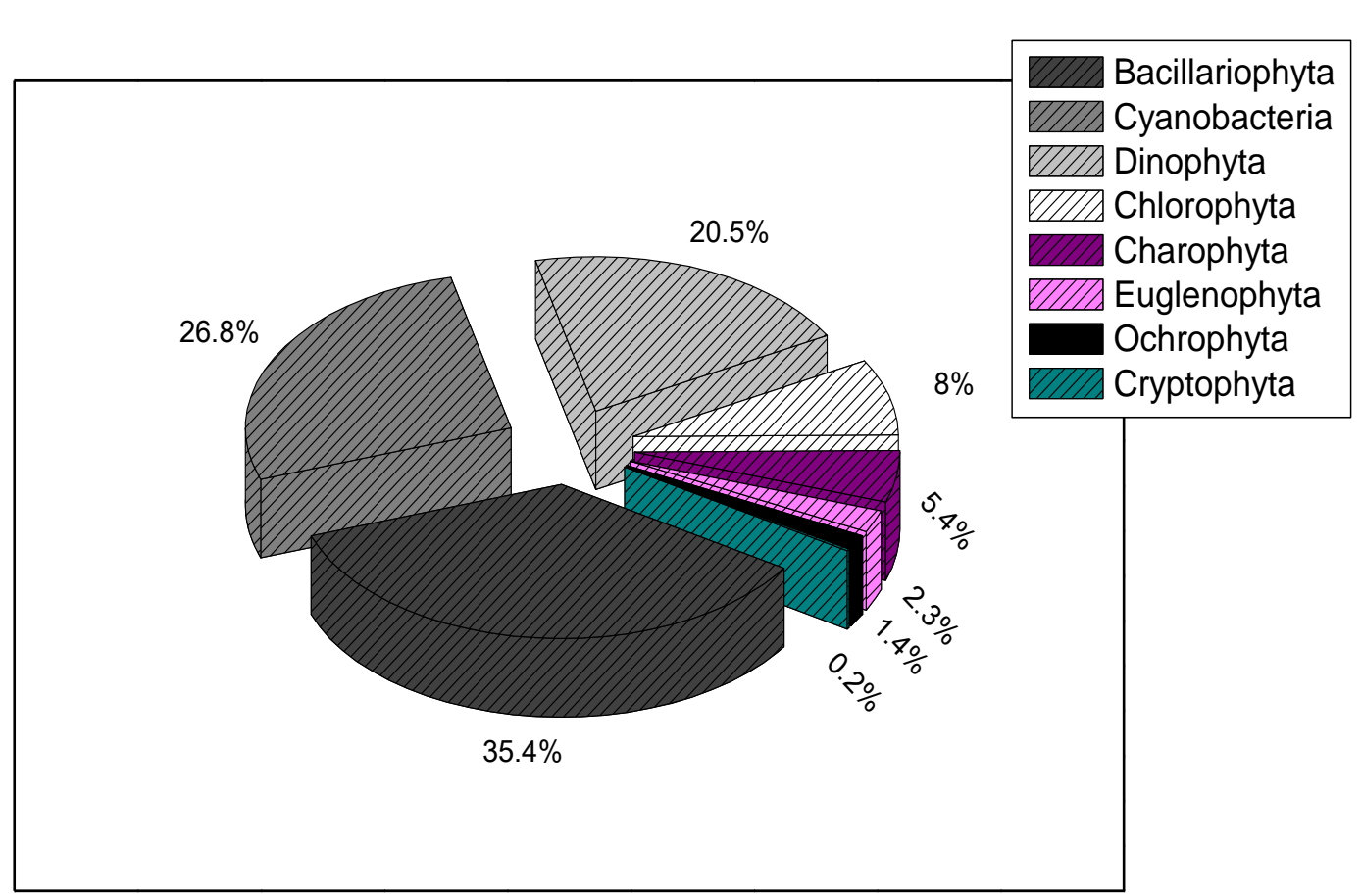

Fig. 2. Annual ratios of phytoplankton phyla in Lake Qarun during 2018-2019

\section{Biochemical components of phytoplankton}

\subsection{Chlorophyll (a) and carotenoid}

Seasonally, winter showed the highest concentration of $\mathrm{Chl}(a)$, with an average seasonal value of $70.61 \mu \mathrm{g} / \mathrm{l}$. On the other side, the least seasonal average value was recorded during spring $(63.68 \mu \mathrm{g} / \mathrm{l})$. The annual average values of $\mathrm{Chl}(a)$ revealed that, the highest content was presented in site (3) (North east of lake) recording $165.77 \mu \mathrm{g} / \mathrm{l}$, while the least concentration was found in El-Wadi and El-Bats drains, with values $31.45 \mu \mathrm{g} / 1$ and $27.57 \mu \mathrm{g} / 1$, respectively. These results are in agreement with those of 
Mosad (2018) who reported that the high concentration of Chl (a) was in January (winter season) in the eastern part of Lake Qarun.

Meanwhile, the highest concentration of carotenoid was showed in the summer season, with a seasonal average of $43.02 \mu \mathrm{g} / \mathrm{l}$, while the least seasonal average value was recorded during spring $(25.03 \mu \mathrm{g} / \mathrm{l})$. The annual average values of carotenoid realized that the highest content reported in site (3) (North east of lake), $125.57 \mu \mathrm{g} / \mathrm{l}$, while the least concentration found in site (7) (Opposite to El-Wadi Drain), El-Bats and El-Wadi drains, $29.84 \mu \mathrm{g} / 1,31.45 \mu \mathrm{g} / 1$ and $27.57 \mu \mathrm{g} / \mathrm{l}$, respectively (Figs. $3 \& 4$ ).

Those results wereconfirmed by Pearson correlation matrix and principal component analysis (PCA) (Fig. 8). Fig. (8) shows that, a transparency and water temperature were negatively correlated with $\mathrm{Chl}(a)(\mathrm{r}=-0.09,-0.33, \mathrm{P}<0.05)$, and carotenoid $(\mathrm{r}=-0.23,-0.27, \mathrm{P}<0.05)$.

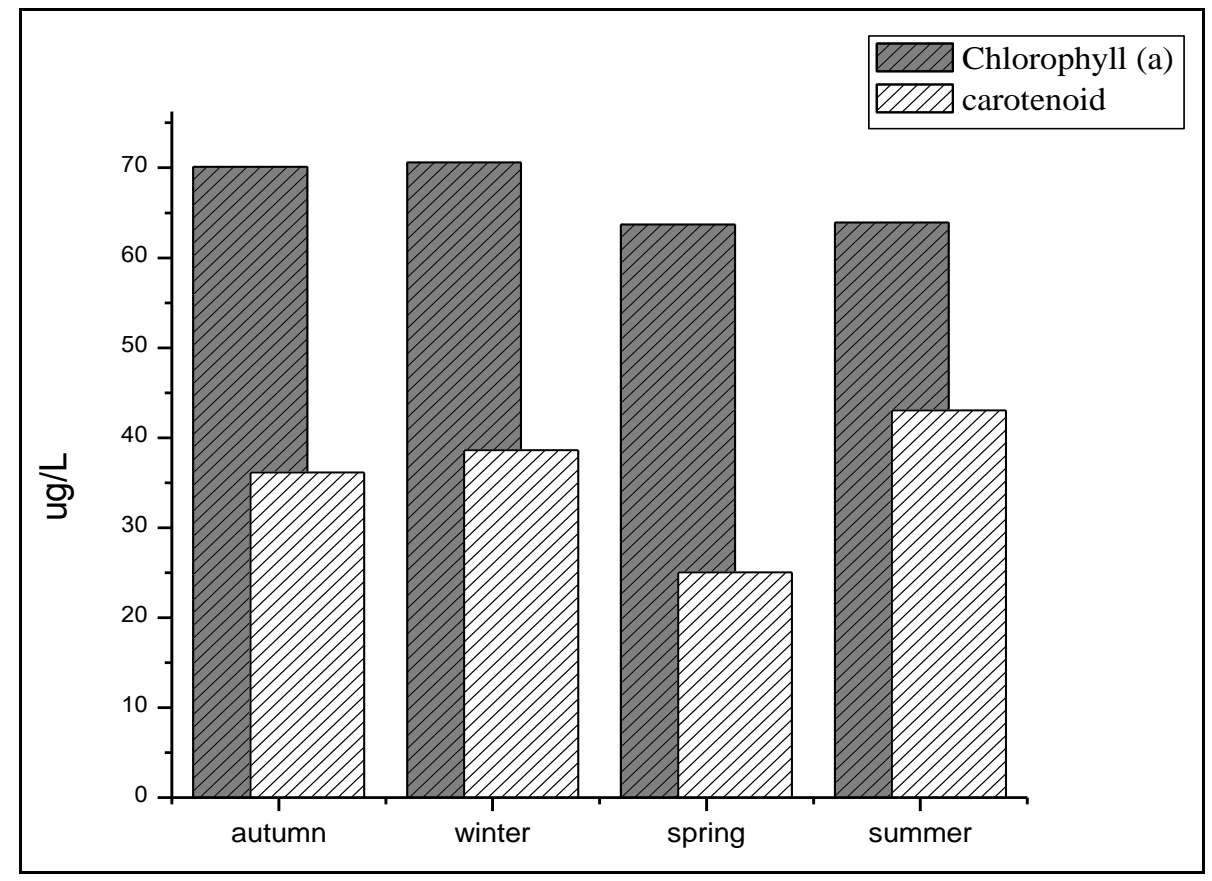

Fig. 3. Seasonal average of chlorophyll $(a)$ and carotenoid ( $\mu \mathrm{g} / \mathrm{l})$ in Lake Qarun during 20182019 


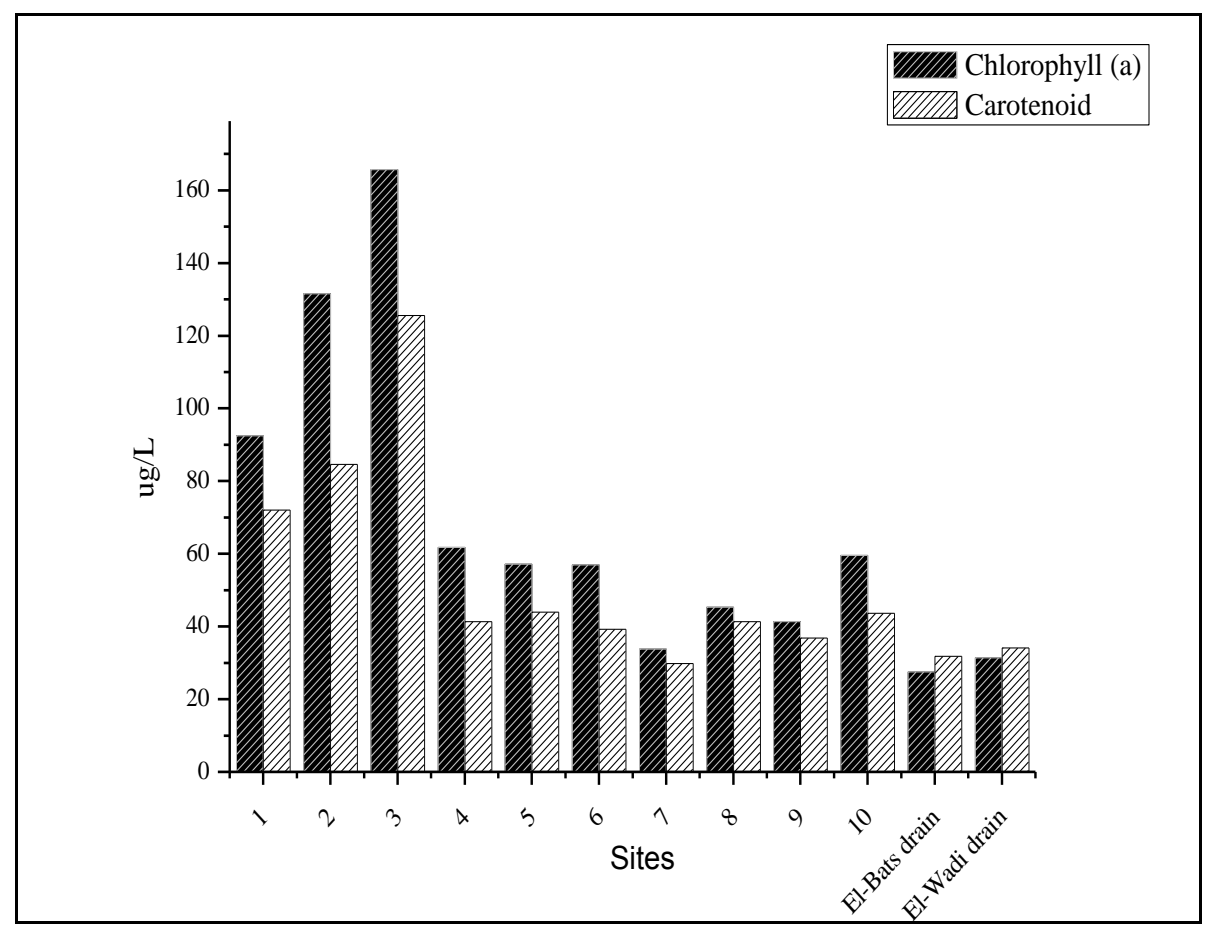

Fig. 4. The annual average of chlorophyll $(a)$ and carotenoid $(\mu \mathrm{g} / \mathrm{l})$ in Lake Qarun during 20182019

\subsection{Protein, carbohydrate and lipid}

The present data found a large variety of biochemical content levels in the phytoplankton communities between species and location during the four seasons.

The maximum protein contents were detected in site (3) (North east of the lake) during winter $(19.77 \mathrm{mg} / \mathrm{l})$, while the minimum value was found in site (9) (West lake) during summer $(0.68 \mathrm{mg} / \mathrm{l})$. The maximum carbohydrate contents were detected in site (7) (Opposite to El-Wadi Drain) during autumn $(3.28 \mathrm{mg} / \mathrm{l})$, while the minimum value was determined in El-Wadi Drain during spring $(0.08 \mathrm{mg} / \mathrm{l})$. The maximum lipid content was detected in site (3) during winter $(0.568 \mathrm{mg} / \mathrm{l})$, while the minimum value wasfound in site (7) (Opposite to El-Wadi Drain) during autumn, and during spring in site (2) (Opposite to El-Auberge) and the sites of El-Wadi and El-Bats (0.003 mg/l) (Fig. 5).

Seasonally, winter showed the highest concentration of protein, carbohydrate and lipid, with an average seasonal value of $10.13,1.3$, and $0.27 \mathrm{mg} / 1$, respectively. On the other side, the least seasonal average value was recorded during spring with values of $3.28,0.29$, and $0.02 \mathrm{mg} / 1$, respectively.

The present results agree with those of Abd El-Hady et al., (2016) who studied phytoplankton biochemical contents in Nasser Lake and showed that the best season for biochemical content was winter.

These results wereconfirmed by Pearson correlation matrix and principal component analysis (PCA) (Fig. 8). It shows that water temperature was in a negatively correlation with protein, carbohydrate and lipid $(\mathrm{r}=-0.83,-0.61,-0.65, \mathrm{P}<0.05)$. 
Mahmoud (2016) deduced a direct relationship between the biochemical contents and the physicochemical and environmental conditions, including nutrients, especially nitrates and phosphates in the River Nile.

Generally, the total protein content constitutes the major part of the biochemical composition of the phytoplankton community, while the total lipid content constitutes the minor one; the phytoplankton biochemical composition is considered a biomarker of the ecosystem of different sites in Lake Qarun.

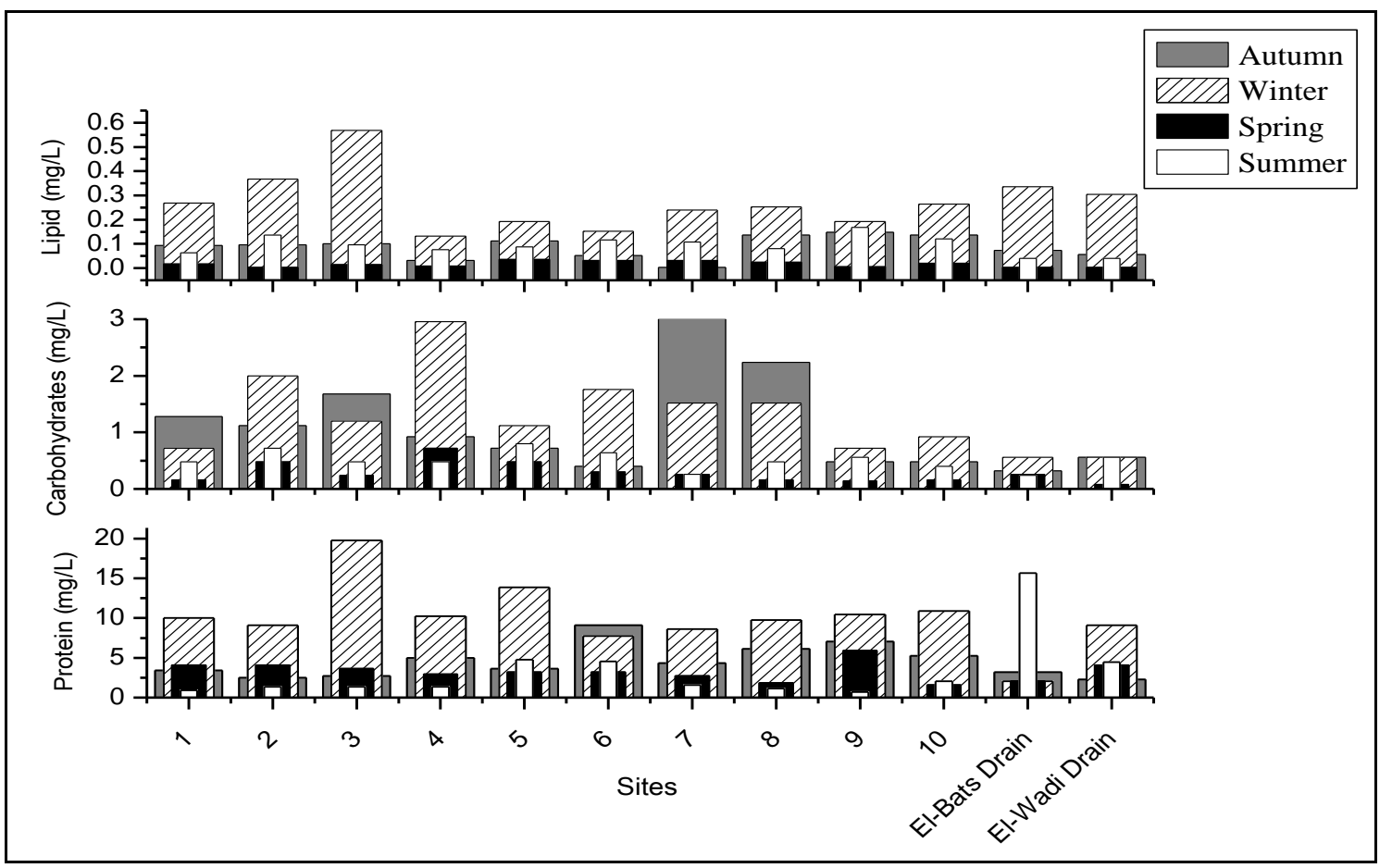

Fig. 5 Biochemical contents of phytoplankton in Lake Qarun during 2018-2019 


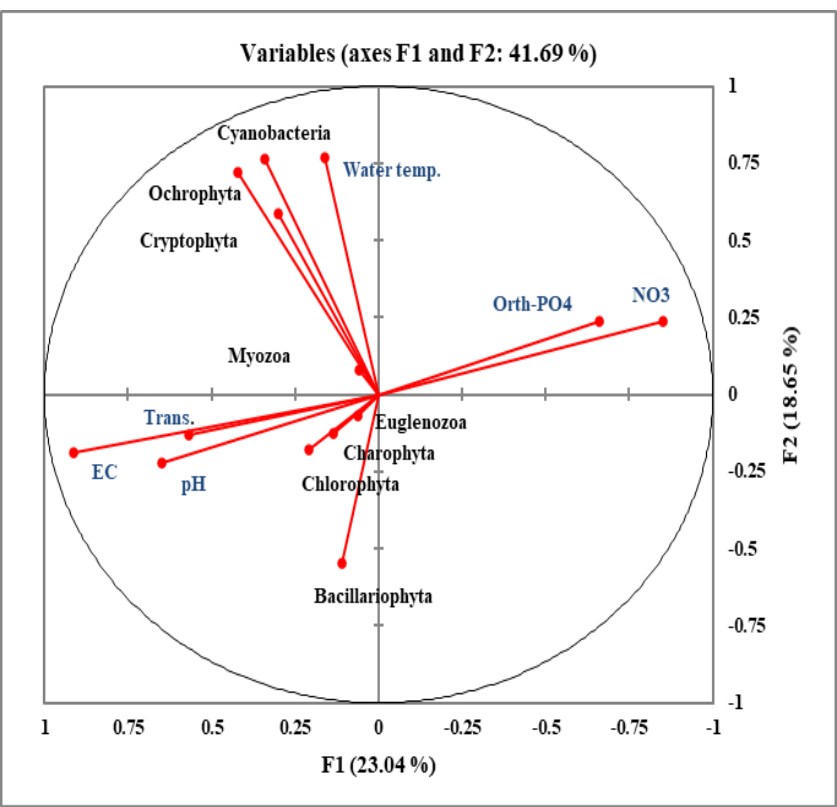

Fig. 6. PCA performed between physico-chemical variables and phytoplankton phyla in Lake Qarun during 2018-2019

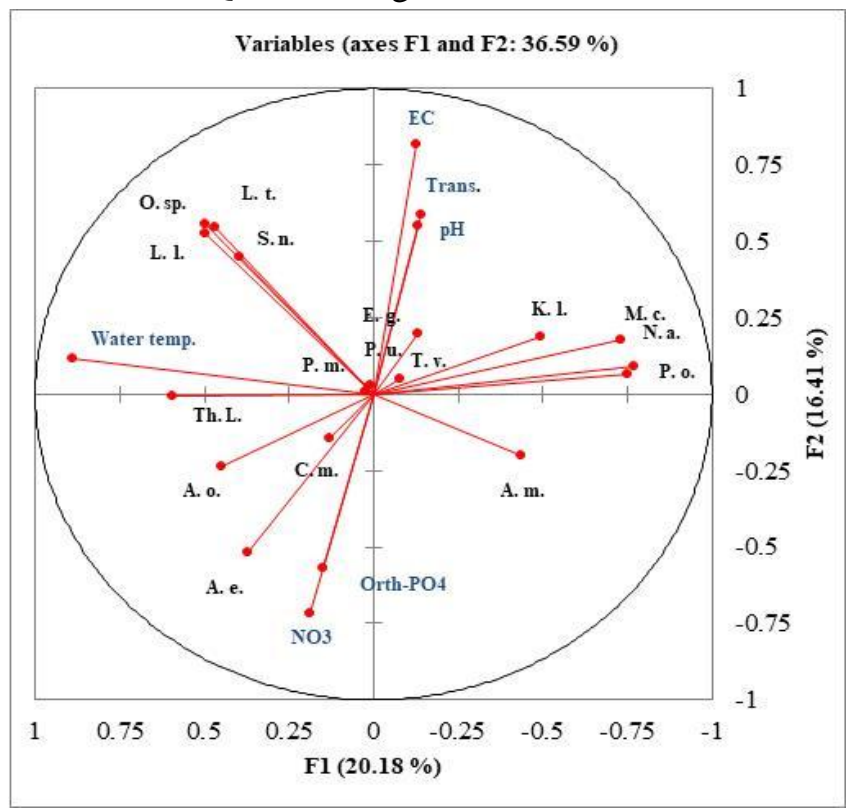

Fig. 7. PCA performed between physico-chemical variables and dominant phytoplankton species in Lake Qarun during 2018-2019 


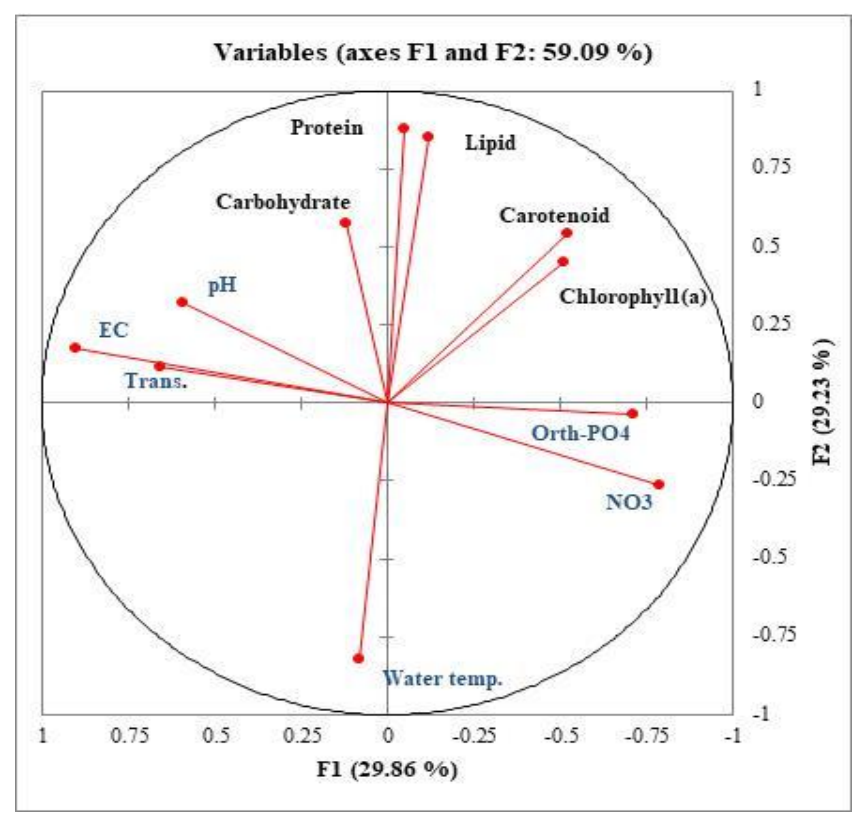

Fig. 8. PCA performed between physico-chemical variables and phytoplankton biochemical contents in Lake Qarun during 2018-2019

\section{CONCLUSION}

Changes in water temperature throughout the seasons of the year affect the quantity and quality of phytoplankton and hence their biochemical contents. From the results mentioned above, it has been concluded that there is a seasonal variation in phytoplankton species, phyla, and its biochemical compounds such as chlorophyll (a), carotenoid, protein, lipid, and carbohydrate in Lake Qarun, which indicates the diversity of phytoplankton species and phyla throughout the year. Moreover, observation of high concentrations of protein and lipid contents of phytoplankton during the winter season could be recognized as the growth-enhancing factor for hydrobionts found in the aquatic environment of Lake Qarun.

\section{ACKNOWLEDGEMENTS}

Sampling and sample processing, data analysis, and manuscript writing were conducted in the framework of the state assignments of the National Institute of Oceanography and Fisheries- Egypt (NIOF). The authors thank Prof. Dr. Mohamed H. Abdo (NIOF) for providing some physicochemical parameters.

\section{REFERENCES}

Abd El-Hady, H. H.; Fathey, S. A.; Ali, G. H. and Gabr, Y. G. (2016). Biochemical profile of phytoplankton and its nutritional aspects in some khors of Lake Nasser, 
Egypt. EJBAS, 3: 187-193. https://doi.org/10.1016/j.ejbas.2016.03.002.

Abdel-Monem, A. M. (2001). Biodiversity of phytoplankton structure in Lake Qarun (ElFayum) and its use as indicators for environmental pollution. Egypt. J. Phycol., 2: 1731. https://www.bibliomed.org/?mno=232221.

Abdel-Monem, A. M. and Kanswa, A. H. (2001). Some biotic and abiotic variables controlling primary productivity in hypertrophic Lake (Lake Qarun- Egypt). EJABF, 5(3): 1-16. https://dx.doi.org/10.21608/ejabf.2001.1686.

Addinsoft SARL (2010). XLSTAT software ver.9.0 [Computer software], Addinsoft, Paris.

APHA (American Public Health Association) (2017). Standard Methods for the examination of water and wastewater. $23^{\text {rd }}$ ed. Washington: $1546 \mathrm{pp}$.

Bellinger, E. G. and Sigee, D. C. (2010). Fresh water algae: Identification and use as bioindicators. $1^{\text {st }}$ edition by John Wiley and Sons, Ltd, 284 pp.

Bellinger, E. G. and Sigee, D. C. (2015). Freshwater algae: identification, enumeration and use as bioindicators. John Wiley \& Sons, Ltd, 275 pp.

Bhavya, P. S.; Kim, B. K.; Jo, N.; Kim, K.; Kang, J. J.; Lee, J. H.; Lee, D.; Lee, J. H.; Joo, H.; Ahn, S. H.; Kim, Y.; Min, J.; Kang, M. G.; Yun, M. S.; Kang, C. K. and Lee, S. H. (2019). A Review on the Macromolecular Compositions of Phytoplankton and the Implications for Aquatic Biogeochemistry. Ocean. Sci. J., 54(1): 1-14. https://doi.org/10.1007/s12601-018-0061-8.

Boëchat, I. G. and Giani, A. (2008). Seasonality affects diel cycles of seston biochemical composition in a tropical reservoir. J. Plankton Res., 30: 1417-1430. https://doi.org/10.1093/plankt/fbn089.

Chabrol, E. and Castellano, A. (1961). SPV method for estimation of total serum lipid. J. Lab. Clin. Med., 57, 300pp.

Danovaro, R.; Dell'Anno, A.; Pusceddu, A.; Marrale, D.; Della Croce, N.; Fabiano, M. and Tselepides, A. (2000). Biochemical composition of pico-, nano- and microparticulate organic matter and bacterioplankton biomass in the oligotrophic Cretan Sea (NE Mediterranean). Prog. Oceanogr., 46: 279-310. https://doi.org/10.1016/ S0079-6611(00)00023-9.

David, J. H. and Hazel, P. (1998). Analytical Biochemistry. Hand book, $3^{\text {rd }}$ ed., Pearson Education, England, 497 P.

Desikachary, T. V. (1959). Cyanophyta. $1^{\text {st }}$ ed. Indian, Council of Agricultural Research, New Delhi, 686 pp.

Dubois, M.; Gilles, K. A.; Hmilton, J. K.; Repers, P. A. and Smith, F. (1956). Colorimetric method of determination of sugars and related substances. Anal. Chem., 18: 350-356. https://doi.org/10.1021/ac60111a017.

El-Shabrawy, G. M. and Dumont, H. J. (2009). The Fayum Depression and Its Lakes. In: Dumont H.J. (eds) The Nile. Monographiae Biologicae, vol 89. Springer, Dordrecht. https://doi.org/10.1007/978-1-4020-9726-3_6. 
Fathi, A. A. and Flower, R. J. (2005). Water quality and phytoplankton communities in Lake Qarun (Egypt). Aquat. Sci., 67: 350-362. https://doi.org/10.1007/s00027-0050777-2.

GAFRD General Authority for Fish Resources Development (2012). Annual fishery statistics report. Cairo, Egypt.

Guiry, M. D. and Guiry, G. M. (2021). AlgaeBase. World-wide electronic publication. Galway: 375 National University of Ireland. https://www.algaebase.org

Httl-Hand, J. G. (1988). II Tetrasporales, Chlorococcales, Gloedendales. Subwasser flora Von Mitteleuropa Herausgegeben Von. H. Ettl. J.Gerloff. H. Heynig D. Mollenhauer. Band 10. Gustay Fischer. Verlag. Stuttgart, New York, 436 pp.

Hussein, H.; Amer, R.; Gaballah, A.; Refaat, Y. and Abdel-Wahab, A. (2008). Pollution Monitoring for Lake Qarun. Adv. Environ. Biol., 2(2): 70-80. http://www.aensiweb.com/old/aeb/2008/70-80.pdf.

Hussian, A. M.; Morsi, H. H. and Goher, M. E. (2014). Microphytobenthos, Meiobenthos and Sediment Quality of Qarun Lake, Egypt. Int. j. Environ, 3(3): 172-183. http://www.curresweb.com/ije/ije/2014/172-183.pdf.

Hussian, A. M.; Bendary, R. E.; Sabae, S. A. and Napiórkowska-Krzebietke, A. (2019). Benthic Algae and Macroinvertebrates in Response to Habitat Conditions and SiteSpecific Fish Dominance: A Case Study of Lake Qarun, Egypt. Turk. J. Fish. Aquat. Sc., 20(4): 241-253. https://doi.org/10.4194/1303-2712-v20_4_01.

Krammer, K. and Lange-Bertalot, H. (1991). Bacillariophyceae 3. Teil: Centrales, Fragillatiaceae, Eunotiaceae. In Ettl, H., Gerloff, J., Heynig, H. \& Mollenhauer, D. (Eds.). Süsswasserflora von Mitteleuropa. 2(3): 1-576. Gustav Fisher Verlag, Stuttgart, Germany.

Lee, R. E. (2008). Phycology. $4^{\text {th }}$ Edition. Cambridge University Press, New York. 547 pp.

Lee, S. H.; Kim, H. J. and Whitledge, T. E. (2009). High incorporation of carbon into proteins by the phytoplankton of the Bering Strait and Chukchi Sea. Cont. Shelf Res., 29: 1689-1696. https://doi.org/10.1016/j.csr.2009.05.012.

Lindqvist, K. and Lignell, R. (1997). Intracellular partitioning of ${ }^{14} \mathrm{CO}_{2}$ in phytoplankton during a growth season in the northern Baltic. Mar. Ecol-Prog. Ser., 152: 41-50. https://doi.org/10.3354/MEPS152041.

Mahmoud, A. M. A. (2016). Regional and Seasonal Variation of Biochemical Contents of Phytoplankton in El-Rayah Al-Nasery and El-Rayah Al-Behery, Nile River, Egypt. Int. J. Fish. Aquat. Stud., 4(1): 259-263. https://www.fisheriesjournal.com/archives/ 2016/vol4issue 1/PartD/3-2-17.pdf.

Mosad, Y. A. (2018). Exploration of red tide and its impact on phytoplankton communities in Lake Qarun, El-Fayoum - Egypt. Ms.c. Thesis, Fac. Sci., Fayoum Univ. 
Munshi, J. D.; Roy, S. P. and Munshi, D. (2010). Manual of Freshwater biota. Narendra Publising House, Delhi; p. 1-455.

Myklestad, S. and Haug, A. (1972). Production of carbohydrate by the marine diatom Chaetoceros affinis var. Willei (Gran) Hustedt. I. Effect of the concentration of nutrients in the culture medium. J. Exp. Mar. Biol. Ecol., 9: 125-136. https://doi.org/10.1016/0022-0981(72)90041-X.

Napiórkowska-Krzebietke, A.; Hussian, A. M.; Abd El-Monem, A. M. and El-Far, A. M. (2016). The relationship between phytoplankton and fish in the nutrient-rich shallow Lake Qarun, Egypt. Oceanol. Hydrobiol. Stud., 45(4): 539-553. https://doi.org/10.1515/ohs-2016-0045.

Parrish, C. C. (1987). Time series of particulate and dissolved lipid classes during spring phytoplankton blooms in Bedford Basin, a marine inlet. Mar. Ecol-Prog. Ser., 35: 129-139. http://doi.org/10.3354/meps035129.

Popovsky, J. and Pfiester, L. (1990). Dinophyceae (Dinoflagellitida) Subwasserflora Von Mitteleuropa, Herausgegeben, Von. H. Ettl. J. Gerloff. H. Heynig D. Mollenhauer. Band 6. Gustav Fischer Verlag. Jena, Stuttgart, 272 pp.

Sharma, R. C. and Tiwari, V. (2018). Phytoplankton diversity in relation to physicochemical environmental variables of Nachiketa Tal, Garhwal Himalaya. Biodivers. Int. J., 2(2): 102-110. https://doi.org/10.15406/bij.2018.02.00052.

Starmach, K. (1974). Flora Slodkowodna Polski. Tom 4. Cryptophyceae Dinophyceae Raphidophyceae, Krakow, 519 pp.

Takagi, M.; Watanabe, K.; Yamaberi, K. and Yoshida, T. (2000). Limited feeding of potassium nitrate for intracellular lipid and triglyceride accumulation of Nannochloris sp. UTEX LB1999. Appl. Microbiol. Biot., 54: 112-117. https://doi.org/10.1007/s002530000333.

Verlencar, X. N. and Desai, S. R. (eds.) (2004). Phytoplankton identification Manual. National Institute of Oceanography, Dona Paula. 35pp.

Ward, H. B. and Whipple, G. C. (1996). Freshwater biology. $3^{\text {rd }}$ ed. John Wiley \& Sons, Inc., New York.

Yun, M. S.; Lee, D. B.; Kim, B. K.; Kang, J. J.; Lee, J. H.; Yang, E. J.; Park, W. G.; Chung, K. H. and Lee, S. H. (2015). Comparison of phytoplankton macromolecular compositions and zooplankton proximate compositions in the northern Chukchi Sea. Deep-Sea Res. Pt. II, 120: 82-90. https://doi.org/10.1016/j.dsr2.2014.05.018. 


$$
\begin{aligned}
& \text { الملخص العربي } \\
& \text { التغيرات الموسمية لتنوع العوالتى النباتية ومكوناتها البيوكيميائية في بحيرة قارون - مصر } \\
& \text { ناصر سليمان فليفل*- عبيز محمد محمود } \\
& \text { المعهد القومي لعلوم البحار و المصايد- مصر }
\end{aligned}
$$

اثنتا عشرة عينة تمثل بحيرة قارون ومصرفين (البطس والوادي). أجريت الدراسة الموسمية لتقدير أعداد

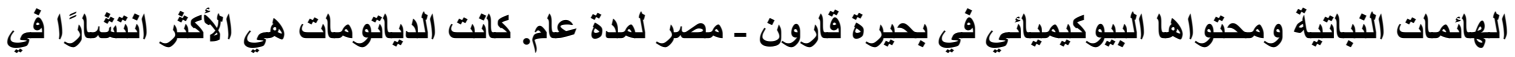

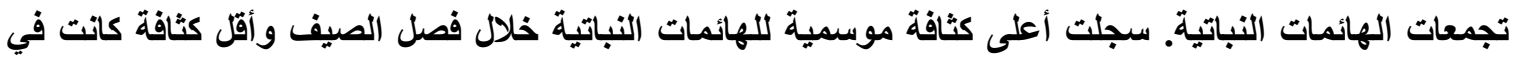

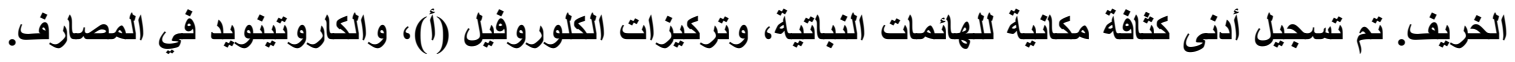
كثف التحليل الإحصائي (ANOVA) عن اختلافات معنوية بين الفصول والمحطات في كثافة أنواع الهائمات

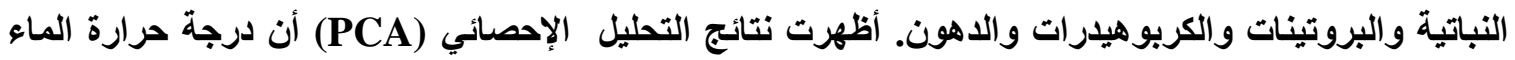
كانت مرتبطة بشكل إيجابي بواسطة Ochrophyta و Cyanobacteria و

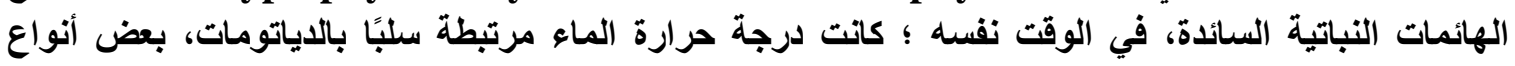

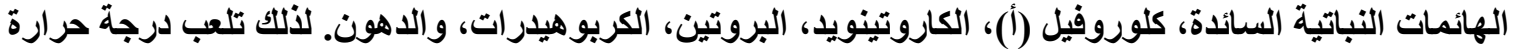

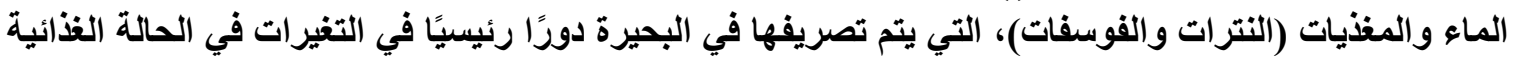

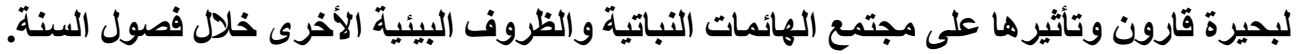

